\title{
HUBUNGAN POSISI BEKERJA PETANI LANSIA DENGAN RESIKO \\ TERJADINYA LOW BACK PAIN DI DESA CANGKRING KECAMATAN JENGGAWAH KABUPATEN JEMBER
}

Eka Suryaning Tyas

\begin{abstract}
Keselamatan dan kesehatan kerja (K3) adalah program yang dibuat pekerja atau pengusaha sebagai upaya mencegah timbulnya kecelakaan dan penyakit akibat kerja (PAK) dengan mengenali hal-hal yang berpotensi menimbulkan kecelakaan dan penyakit akibat kerja serta tindakan antisipatif terjadinya kecelakaan dan penyakit akibat kerja. Penelitian ini menggunakan menggunakan metode penelitian komparasi, dimana metode ini bertujuan untuk mengkaji hubungan antara variable independen dan variable dependen pada sekelompok subyek. Populasi dalam penelitian ini adalah seluruh petani lansia di wilayah kerja Desa Cangkring Kabupaten Jember yang berjumlah 40 orang. Wilayah kerja Desa Cangkring Kabupaten Jember,hasil yang di dapat yaitu posisi bekerja dengan low back paint sebanyak 14 orang(20,0\%),dapat dilihat bahwa posisi bekerja dengan low back paint sebanyak 14 orang(20,0\%), sedang kanposisi kerja membungkuk sedang sebanyak 6 orang $(8,6 \%)$, posisi kerja saat sebanyak 0 orang $(0,0 \%)$, posisi kerja berdiri dengan risiko kerja 0 orang $(0,0 \%)$, posisi kerja membungkuk dengan risiko kerja 33 orang $(47,1 \%)$, sebanyak 3 orang $(4,3)$ posisi kerja petani lansia dengan risiko kerja low back pain sebanyak 10 siswa $(14,3 \%)$.
\end{abstract}

Kata kunci : Posisi bekerja,petani lansia, Low back pain.

Daftar Pustaka : 40 ( 1997-2013)

PENDAHULUAN

Data Desa Cangkring tahun 2013.Menunjukan ada 34 orang warga di Desa Cangkring melaporkan adanya keluhan Low Back Pain, dan 34 orang diantaranya bekerja sebagai petani, Pada saat peneliti melakukan observasi sekaligus wawancara terhadap 34 orang tersebut, peneliti mendapatkan data bahwa para petani tersebut tidak memperhatikan posisi-posisi pada saat bekerja karena bekerja seperti petanipetani pada umumnya. 
Berdasarkan studi pendahuluan yang dilakukan penulis di Desa Cangkring Kecamatan Jenggawah Kabupaten Jember pada bulan Oktober 2014, diketahui bahwa jumlah lansia yang bekerja sebagai petani di wilayah Desa Cangkring sebanyak 40 orang, dengan keluhan nyeri Low Back Pain 35 orang. Hasil dari wawancara peneliti, dari 40 orang tersebut yang mengalami keluhan Low Back Pain tersebut hanya 34 orang yang dikarenakan posisi yang posisi yang kurang tepat (misal: posisi terlalu membungkuk, berjongkok terlalu lama, mengangkat atau memindahkan karung padi maupun beras secara tidak ergonomi), Lansia memiliki jam kerja dan beban kerja yang sama dengan penduduk produktif pada umumnya.

Lansia yang bekerja di sektor informal bekerja mulai pukul 06:00 sampai dengan dengan pukul 16:00. Para lansia harus bekerja 10 jam dalam sehari. Beban kerja lansia juga tidak berbeda dengan masyarakat di usia produktif. Proses degeneratif dan keadaan tidak mendukung yang bersumber dari bidang ekonomi membuat lansia membutuhkan suatu upaya pencegahan untuk menghindari terjadinya penyakit akibat kerja yang muncul pada lansia.
Hasil survei Badan Pusat Statistik (BPS) (2012), dominasi penggunaan lahan di wilayah kota jember adalah kegiatan pertanian yakni seluas 5.099,283 Ha atau $51,47 \%$ dari total luas wilayah kota.Tanah perkebunan seluas 1.477,9 $\mathrm{Ha}$ atau $14,92 \%$.Perumahan seluas 2.679,655 Ha atau 27,05\%.Kolam ikan seluas 1,0 $\mathrm{Ha}$ atau $0,01 \%$ dan penggunaan tanah lain-lainnya seluas 416,415 $\mathrm{Ha}$ atau $4,20 \%$,pertanian dilihat sebagai suatu yang potensial dalam kontribusinya terhadap perekonomian di indonesia dan juga dinilai dapat memiliki berbagai macam resiko kesehatan dalam pelaksanaan ,hal tersebut di karenakan pekerjaan petani masih belum memiliki standart keselamatan kesehatan kerja (k3)

Hasil penelitian Mandayanti (2012), tentang lansia di sektor informal,didapatkan hasil faktor lansia di indonesia masih bekerja disebabkan oleh adanya kondisi dalam keluarga yang menyangkut keadaan ekonomi keluarga. Hal tersebut meliputi kebutuhan hidup keluarga, faktor ekonomi, penghasilan yang tidak tetap, adanya kesempatan kerja, serta adanya rasa kemandirian dalam diri lansia. Penduduk lanjut usia merasa masih mampu dalam bekerja dan merasa tidak berguna apabila hanya berdiam diri di rumah. Kondisi tersebut 
berpengaruh terhadap status kesehatan lansia, sehingga resiko penyakit atau kecelakaan akibat kerja juga semakin tinggi.

Dari paparan diatas maka peneliti tertarik melakukan penelitian mengenai Hubungan Posisi Bekerja Petani Lansia Dengan Resiko Terjadinya Low Back Pain di wilayah Desa Cangkring Kabupaten Jember. Penelitian ini diharapkan dapat menambah informasi untuk membantu tenaga kesehatan di kecamatan Jenggawah khususnya di Wilayah Desa Cangkring dalam upaya pencegahan dan penanganan penyakit akibat kerja, salah satu contohnya menurunkan resiko terjaadinya Low Back Pain pada petani lansia dengan cara peningkatan kesadaran melakukan cara kerja sesuai dengan posisi kerja yang ergonomi. Sehingga dapat memaksimalkan program Keselamatan dan Kesehatan Kerja (K3) di Wilayah Desa Cangkring Kabupaten Jember.

\section{Rumusan Masalah}

Berdasarkan latar belakang diatas peneliti merumuskan masalah “ Apakah ada hubungan posisi bekerja petani lansia dengan resiko terjadinya Low Back Pain di wilayah kerja Desa Cangkring?"

\section{Tujuan Peneliti}

1. Tujuan Umum

Menganalisis hubungan posisi bekerja petani lansia dengan resiko terjadinya Low Back Pain di Wilayah Kerja Desa Cangkring Kecamatan Jengawah Kabupaten Jember

2. Tujuan Khusus

a. Mengidentifikasi posisi bekerja pada petani lansia di wilayah Desa Cangkring Kabupaten Jember

b. Menganalisis resiko terjadinya Low Back Pain di wilayah Desa Cangkring Kabupaten Jember

\section{METODE PENELITIAN}

Desain penelitian merupakan hasil akhir dari suatu tahap keputusan yang dibuat oleh penelitian berhubung dengan bagaimana suatu konsep diterapkan (Nursalam, tahun 2003).

Dalam penelitian ini menggunakan metode penelitian komparasi, dimana metode ini bertujuan untuk mengkaji hubungan antara variable independen dan variable dependen pada sekelompok subyek.

Dalam penelitian ini berdasarkan waktu menggunakan cross sectional, yaitu jenis penelitian yang menekankan waktu pengukuran /observasi data 
variable indenpenden dan dependen hanya satu kali pada satu saat (Nursalam , tahun 2013). Tiap subyek penelitian hanya diobservasi satu kali saja dan pengukuran variabel diukur dan dianalisa saat pemeriksaan atau pengkajian saja.

Populasi dalam penelitian ini adalah seluruh petani lansia di wilayah kerja Desa Cangkring Kabupaten Jember yang berjumlah 40 orang. Wilayah kerja Desa Cangkring Kabupaten Jember

Sampel ini menggunakan kreteria inklusi dan eksklusi yaitu kreteria inklusi
Lansia yang bekerja di sektor pertanian di wilayah Desa Cangkring yang mengalami nyeri punggung bawah dan Bersedia menjadi responden

Untuk Kriteria Esklusi yaitu yang Tidak ada saat penelitian karena sakit atau bepergian dan Tidak koperatif.

\section{HASIL PENELITIAN}

Penelitian dilakukan pada Tanggal 13 Oktober 2014 sampai dengan 16 Maret 2015 Di Desa Cangkring Kecamatan Jenggawah di dapatkan :

\section{Tabel 1}

Distribusi Posisi Berkerja Petani Lansia Resiko Kabupaten Jember

\begin{tabular}{ccc}
\hline PerilakuMerokok & Frekuensi & Prosentase $(\%)$ \\
Tidak beresiko & 13 & 21,4 \\
Tidak tahu & 17 & 60,0 \\
beresiko & 10 & 18,6 \\
Total & 40 & 100,0 \\
\hline
\end{tabular}

Berdasarkan tabel 5.1 sebagian besar responden mempunyai risiko dalam kategori sedang yaitu $40(60,0 \%)$.

\section{Tabel 3}

Tabulasi silang Posisi Berkerja Petani Lansia dengan Resiko Low Back Pain Kabupaten Jember

\begin{tabular}{|c|c|c|c|c|c|c|}
\hline \multirow{2}{*}{ Posisis petani bekerja } & \multicolumn{3}{|c|}{ Risiko low back pain } & \multirow{2}{*}{ Total } & $\begin{array}{c}\text { P } \\
\text { value }\end{array}$ & $\begin{array}{c}\text { Koofesien } \\
\text { Korelasi }\end{array}$ \\
\cline { 2 - 5 } & Berat & Sedang & Ringan & & & \\
\hline Tidak beresiko & 14 & 6 & 0 & 20 & & \\
Presentase & $20,0 \%$ & $8,6 \%$ & $0,0 \%$ & $28,6 \%$ & & \\
\hline Tidak tahu & 0 & 33 & 3 & 36 & \multirow{2}{*}{0,000} & 0,882 \\
Presentase & $0,0 \%$ & $47,1 \%$ & $4,3 \%$ & $51,4 \%$ & & \\
\hline Beresiko & 1 & 3 & 10 & 14 & & \\
Presentase & $1,4 \%$ & $4,3 \%$ & $14,3 \%$ & $20,0 \%$ & & \\
\hline
\end{tabular}




\begin{tabular}{|c|c|c|c|c|c|c|}
\hline Total & 15 & 42 & 13 & 70 & & \\
Presentase & $21,4 \%$ & $60,0 \%$ & $18,6 \%$ & $100 \%$ & & \\
\hline
\end{tabular}

Pada tabel 5.5 dapat dilihat bahwa posisi bekerja dengan low back paint sebanyak 14 orang $(20,0 \%)$, sedang kanposisi kerja membungkuk sedang sebanyak 6 orang $(8,6 \%)$, posisi kerja saat sebanyak 0 orang $(0,0 \%)$, posisi kerja berdiri dengan risiko kerja 0 orang $(0,0 \%)$, posisi kerja membungkuk dengan risiko kerja 33 orang $(47,1 \%)$, sebanyak 3 orang $(4,3)$ posisi kerja petani lansia dengan risiko kerja low back pain sebanyak 10 siswa $(14,3 \%)$.

\section{PEMBAHASAN}

Postur kerja tidak ergonomi merupakan faktor resiko pada terjadinya musculoskeletal disorder karena postur kerja tidak ergonomi, otot, tulang, dan sendi kerja berlebihan dapat memberikan tekanan atau gaya untuk mempertahankan keseimbangan posisi tubuh tertentu.

Postur tubuh tidak ergonomi akan meningkatkan resiko terjadinya musculoskeletal disorde. Gabungan antar beberapa faktor resiko seperti durasi, frekuensi, intensitas, repetitif, dan adanya intervensi stressor dari lingkungan (Kurniawati, 2009).

Faktor yang berhubungan dengan keluhan nyeri punggung bawah pada pekerja bongkar muat barang pelabuhan nusantara kota pare-pare didapatkan hasil pekerja dengan kategori umur tua (> 40 Tahun) lebih banyak yang positif mengalami nyeri punggug bawah yaitu $95,8 \%$ dengan nilai $p$ value $=0,028$ dan pekerja dengan kategori sikap kerja ergonomis lebih banyak yang mengalami nyeri punggung bawah yaitu 81,3\% dengan nilai $p$ value $=0.197$ (Nurwahyuni, et al 2012).

Hasil penelitian wongso (2001), tentang analisa resiko ergonomi terhadap timbulnya low back pain pada manual handing di PT.PENI. Didapatkan hasil manual handing menempati porsi yang cukup besar yaitu sebesar 30\%. Dan seluruh cedera akibat manual handling. Secara umum bentuk cdera akibat pekerjaan manual handling sebagian besar berupa gangguan obat rangka (musculoskeletal disorder), sprain dan strain yaitu sebesar 93,7\%.

a. Pedoman posisi kerja berdiri

Posisi yang benar pada saat berdiri adalah dengan tulang belakang yang lurus dan beban dari tubuh terbagi rata pada keua tungkai. Ukuran tubuh yang penting dalam bekerja dengan posisi badan berdiri adalah tinggi badan pada saat berdiri, tinggi bahu, tinggi siku, 
tinggi pinggul, dan panjang lengan. Bekerja dalam posisi berdiri dalam jangka waktu yang lama akan terdapat penumpukan penumpukan darah dan berbagai cairan tubuh pada kaki. Hal tersebut juga akan mengakibatkan enahanan yang kuat pada ligamen pergelangan kaki, dan apabila itu terjadi dalam jangka waktu yang lebih lama lagi maka otot rangka akan mudah mengalami kelelahan (Napitupulu, 2009)

b. Pedoman posisi kerja membungkuk

Posisi membungkuk adalah posisi tubuh dengan tulang belakang melengkung kedepan melebihi batas normal yaitu melebihi $40 \%$. Posisi membungkuk yang tidak ergonomi membuat punggung tegang, hal tersebut dapat menyebabkan gangguan pada region lumbal dan otot-otot punggung dan hampir semua otot lain kareana otot juga terlibat dalam posisi ini (Napitupulu, 2009).

c. Pedoman posisi kerja pada saat mengangkat

Posisi yang benar pada saat mengangkat tidak boleh bertumpu pada pinggang karean daerah pinggang sangat memungkinkan terjadinya dislokasi otot yang menyediakan rasa sakit pada pinggang, beban tumpuan harus pada daerah kaki (betis, lutut, dan paha) yang lebih kuat dari pada pinggang, kesalahan tumpuan yang dilakukan secara terus menerus akan dapat mengakibatkan terjadinya cedera. Beban yang terlalu berat dapat menimbulkan cedera tulang punggung, jaringan otot, dan persendian akibat gerakan yang berlebihan (Napitupulu, 2009).

\section{Resiko Ergonomi}

Bentuk postur tubuh tidak normal pada saat bekerja adalah pergeseran gerakan tubuh atau anggota gerak yang dilakukan oleh pekerja saat melakukan aktifitas normal bekerja dan dilakukan secara berulang-ulang dalam waktu yang relatif lama. Posisi tubuh yang tidak normal akan menyebabkan gangguan., dalam bentuk cedera pada sistem muskuloskeletal (Sofyan, 2008).

Berdasarakan hasil penelitian posisi bekerja low back pain dalam kategori tidak beresiko 15 orang $(21,4 \%)$, sedang kanposisi kerja membungkuk sedang sebanyak 6 orang $(8,6 \%)$.

Keselamatan dan kesehatan kerja (K3) adalah program yang dibuat pekerja atau pengusaha sebagai upaya mencegah timbulnya kecelakaan dan penyakit akibat 
kerja (PAK) dengan mengenali hal-hal yang berpotensi menimbulkan kecelakaan dan penyakit akibat kerja serta tindakan antisipatif terjadinya kecelakaan dan penyakit akibat kerja (Lestari,2007).

Ternyata pada penelitian ini hasilnya sesuai dengan pendapat Lestari, 2007 yaitu ada hubungan antara posisi bekerja petani lansia dengan risiko terjadinya low back pain.

Berdasarkan uji statistic Pearson diperoleh nilai $r=0,882$, yang berarti ada hubungan posisi bekerja petani lansia dengan risiko terjadinya low back pain $88 \%$ dengan $\mathrm{P}$ value sebesar 0,000 . Karena $\mathrm{P}$ value $<0,05$ maka dapat disimpulkan $\mathrm{H} 1$ diterima $\mathrm{Ho}$ di tolak yang artinya hubungan posisi bekerja petani lansia dengan risiko terjadinya low back pain..

\section{KETERBATASAN PENELITIAN}

Tidak dilakukan uji validitas ulang setelah dilakukan revisi kuesionernya, sehingga ada kemungkinan tidak valid lagi

\section{IMPLIKASI}

UNTUK

KEPERAWATAN
Hasil penelitian ini dapat diterapkan pada penduduk khususnya petani hubungan posisi bekerja petani lansia dengan risiko terjadinya low back pain.

Selain itu perawat sebagai pendidik diharapkan paham dan mengerti $\mathrm{k} 3$ di masyarakat itu masih kurang dan bisa di atasi dengan cara memberikan penyuluhan.

Pada ilmu keperawatan dalam penelitian ini sangat berrguna karena dapat memberikan masukan bagi pengembangan ilmu keperawatan komunitas terutama dalam memberikan asuhan keperawatan kommunitas pada kelompok petani lansia.

\section{KESIMPULAN DAN SARAN}

\section{KESIMPUAN}

Berdasarkan hasil penelitian didapatkan menunjukan sebagian besar posisi bekerja dengan low back paint sebanyak 14 orang(20,0\%), sedang kanposisi kerja membungkuk sedang sebanyak 6 orang $(8,6 \%)$, posisi kerja saat sebanyak 0 orang $(0,0 \%)$, posisi kerja berdiri dengan risiko kerja 0 orang $(0,0 \%)$, posisi kerja membungkuk dengan risiko kerja 33 orang $(47,1 \%), \quad$ sebanyak 3 orang $(4,3)$ posisi kerja petani lansia dengan 
risiko kerja low back pain sebanyak 10 siswa $(14,3 \%)$.

Ada hubungan posisi bekerja petani lansia dengan resiko terjadinya low back pain di desa cangkring kecamatan jenggawah kabupaten jember.p

\section{SARAN}

1. Untuk Peneliti selanjutnya Supaya lebih memperluas faktor yang mempengaruhi terjadinya low back pain

2. Para pendidik supaya memberikan perhatian lebih dalam bimbingan konseling supaya bisa berkurang dan tau caranya posisi yang benar supaya tidak terjadi low baick pain.

3. Untuk Instansi keperawatan

Dapat dijadikan acuan dalam pendidikan kesehatan untuk menekan jumlah low back pain.

DAFTAR PUSTAKA

Hurlock, B. Elizabeth. (2003). Psikologi Perkembangan Suatu pendekatan Sepanjang Rentang Kehidupan Edisi 5, Jakarta: Erlangga
Mu'tadin, Z. (2002). Kemandirian Sebagai Kebutuhan Psikologis Pada lansia. http://www.epsikologi.com/remaja.050602.

Diakses tanggal 17 mei 2013

Notoatmodjo, S, 2007. Pengembangan Sumber Daya Manusia. PT Rineka Cipta,

Santoso, Slamet, 2004, Dinamika Kelompok, Jakarta: Bumi Aksara

Santrock, W. John. (2003). Adolescence Perkembangan Remaja. Jakarta: Erlangga.

Sarwono,. (2006), Psikologi petani. Jakarta: Rajawali Pers.

Sitepoe, M, 1997. Low back pain Cetakan I. Penerbit PT Gramedia Widiasarana Indonesia, Jakarta.

Soerjono Soekanto 1997, Sosiologi; Suatu Pengantar, Jakarta: Universitas Indonesia

World Health Organization. (2001). Smoking Behavior (2001). http:WHO. Int. Diakses pada tanggal 3maret 2013 